\title{
Biology and Impacts of Pacific Island Invasive Species. 1. A Worldwide Review of Effects of the Small Indian Mongoose, Herpestes javanicus (Carnivora: Herpestidae) ${ }^{1}$
}

\author{
Warren S. T. Hays ${ }^{2}$ and Sheila Conant ${ }^{3}$
}

\begin{abstract}
The small Indian mongoose, Herpestes javanicus (E. Geoffroy SaintHilaire, 1818), was intentionally introduced to at least 45 islands (including 8 in the Pacific) and one continental mainland between 1872 and 1979. This small carnivore is now found on the mainland or islands of Asia, Africa, Europe, North America, South America, and Oceania. In this review we document the impact of this species on native birds, mammals, and herpetofauna in these areas of introduction.
\end{abstract}

The small Indian mongoose has been introduced to numerous islands, including eight in the Pacific. Beyond its native range in southern Asia, this species now occurs on islands or mainlands elsewhere in Asia, Africa, Europe, North America, South America, and Oceania. Its negative effects on native biota of these areas are a concern to natural-area managers.

NAME

Herpestes javanicus (E. Geoffroy Saint-Hilaire, 1818)

Synonym: Herpestes auropunctatus (Hodgson, 1836)

Common names: Small Indian mongoose, small Asian mongoose, Javan mongoose

DESCRIPTION

The small Indian mongoose, Herpestes javanicus (E. Geoffroy Saint-Hilaire, 1818) (Figure

\footnotetext{
${ }^{1}$ Manuscript accepted 19 April 2006.

2 Department of Biology, Hawai'i Pacific University, Honolulu, Hawai'i 96813 (e-mail: whays@hpu.edu).

${ }^{3}$ Department of Zoology, University of Hawai'i at Mānoa, Honolulu, Hawai'i 96822.
}

Pacific Science (2007), vol. 61, no. 1:3-16

(C) 2007 by University of Hawai'i Press

All rights reserved
1), typically has an adult body mass in the range of 300 to $900 \mathrm{~g}$ and a body length from 500 to $650 \mathrm{~mm}$ (Nellis 1989). It has the slender body shape typical of the herpestid family, with short legs, short brown fur, and a tail that makes up roughly $40 \%$ of the animal's total length. Dentition is $3: 1: 4: 2$, with a wide carnassial shear region. Females have 36 chromosomes and males have 35, because the $\mathrm{Y}$ chromosome has translocated onto an autosome (Fredga 1965).

A more complete species description may be found in Nellis (1989).

\section{DIET}

No study has yet been done on the diet of the small Indian mongoose in its native range (Figure 2). Table 1 summarizes studies of small Indian mongoose diets in various areas of introduction. In all these studies, except that from Korcula, Croatia, this species of mongoose was found to be an omnivore that is primarily insectivorous and secondarily a hunter of small vertebrates.

The most extensive of these studies was that of Gorman (1975), who examined 4,404 mongoose scats on Viti Levu, Fiji. He found that diets varied according to habitat. For example, crabs were the main food item in mangrove forests, rats were most common in cane-field scats, and cockroaches were most common in scats from urban areas. On Korcula, the mongooses were found to be primarily frugivorous (Cavallini and Serafini 


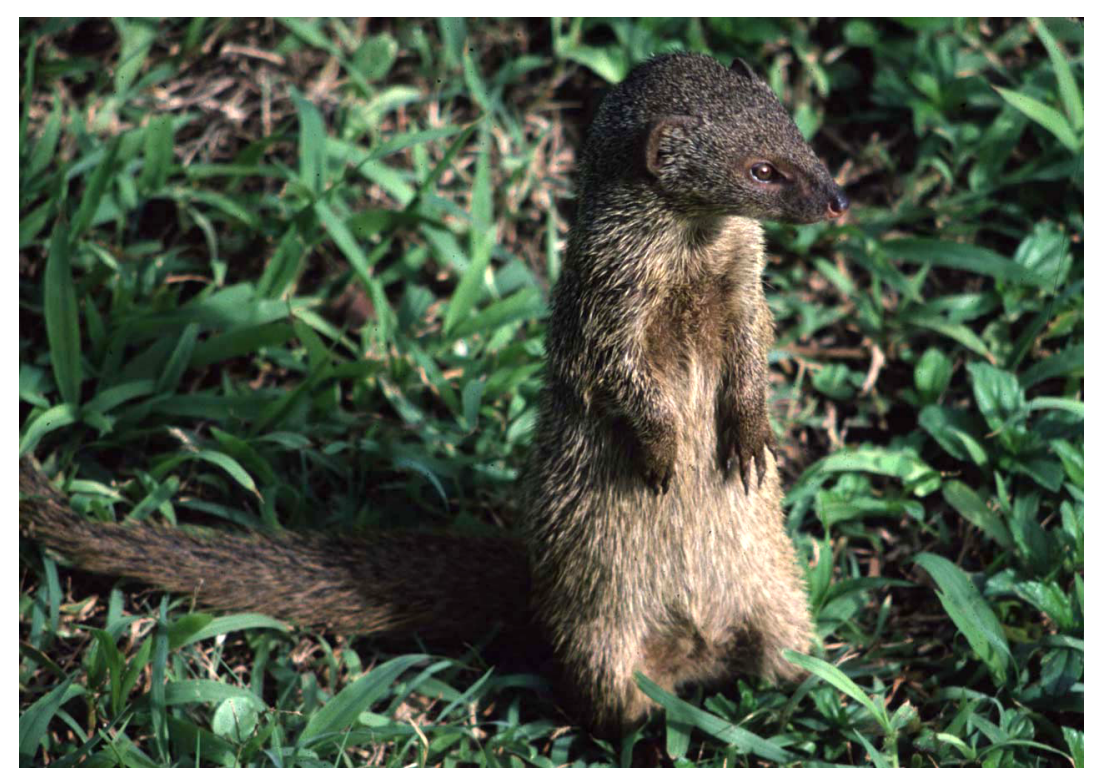

Figure 1. The small Indian mongoose, Herpestes javanicus. Photo by R. J. Shallenberger.

1995). That study was conducted during December and January in a temperate environment, so the seasonally high abundance of the fruits of juniper (funiperus oxycedrus) and strawberry tree (Arbutus unedo) and low abundance of insect prey may have affected food choice.

In all of the studies listed in Table 1, mammal prey was mainly murid rodents: the house mouse (Mus musculus), Norway rat (Rattus norvegicus), and roof rat (R. rattus); however, Cavallini and Serafini (1995) found that mongooses on Korcula preyed upon every available species of small mammal except shrews (Insectivora: Soricidae), which are avoided by many species of predators. Insect prey was varied in most studies, including substantial numbers of orthopterans, coleopterans, and lepidopterans. Mostello (1996) found a preponderance of cockroaches (Orthoptera: Blattidae) among invertebrates in scats from two Hawaiian sites: Lualualei Valley, O'ahu, and Mo'omomi dunes, Moloka'i.

Small Indian mongooses have been observed to eat toads (family Bufonidae), including the parotid glands, which many predators find noxious (Nellis and Everard 1983). By comparison, cats refuse to eat toads, and dogs that consume toads typically become sick or even die. Mongooses also eat littoral animals in Hawai' $\mathrm{i}$, including crabs (suborder Brachyura) (La Rivers 1948, Baldwin et al. 1952). Nellis and Everard (1983) found them to refuse land crabs (Cardisoma guanhumi) persistently on St. Croix, U.S. Virgin Islands, though Wolcott (1953) found this species of crab in 4 of 108 examined mongoose stomachs from St. Croix and Puerto Rico.

La Rivers (1948) examined the contents of 23 mongoose stomachs from Pearl Harbor, $\mathrm{O}^{\prime} \mathrm{ahu}$, and reported that reptiles were a large part of the diet. He also described two individuals working together to hunt crabs (Metapograpsus messor). One turned over stones and the other attacked any crabs that emerged.

Nellis and Everard (1983) kept captive mongooses for several years on a diet consisting of $50 \%$ pork liver and $50 \%$ ripe papaya, with no water other than that contained in the foodstuffs. They reported that mango and papaya were favored foods of captive and hand-raised animals. 


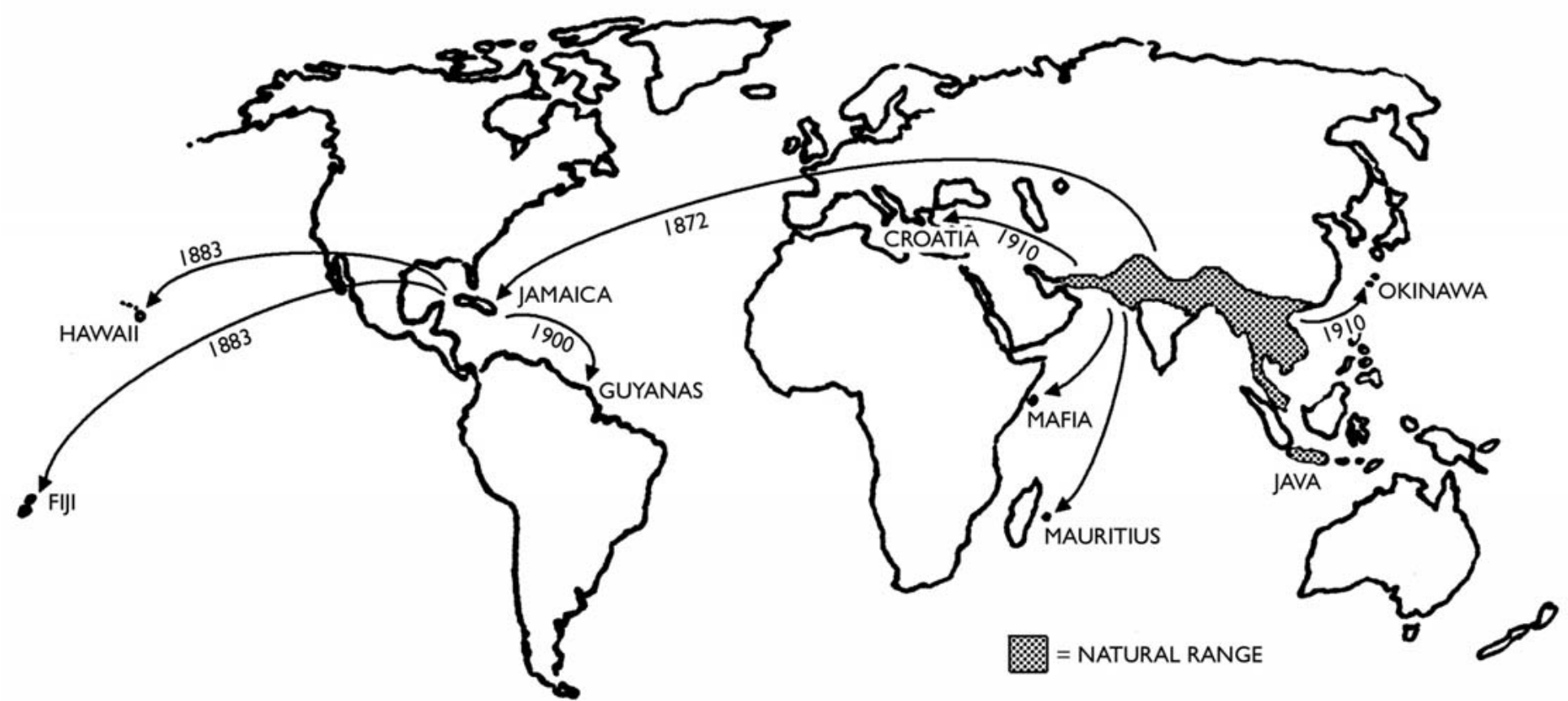

Figure 2. Native range and routes of introduction of the small Indian mongoose. 
TABLE 1

Diet of the Small Indian Mongoose as Determined by Scatological and Stomach Samples

\begin{tabular}{lcccccc}
\hline \hline Diet & St. Croix & Puerto Rico & Fiji & Korcula & Hawai ${ }^{3}{ }^{5}$ & Hawai $^{6} \mathrm{i}^{6}$ \\
\hline (Sample size) & $(36)$ & $(56)$ & $(4,404)$ & $(126)$ & $(86)$ & $(73)$ \\
Mammals & $18 \%$ & $3 \%$ & $10 \%$ & $26 \%$ & $29 \%$ & $39 \%$ \\
Birds & $5 \%$ & $0 \%$ & $4 \%$ & $13 \%$ & $8 \%$ & $3 \%$ \\
Herpetofauna & $9 \%$ & $6 \%$ & $19 \%$ & $0 \%$ & $0 \%$ & $2 \%$ \\
Invertebrates & $59 \%$ & $70 \%$ & $44 \%$ & $16 \%$ & $45 \%$ & $86 \%+$ \\
Plants & $11 \%$ & $11 \%$ & $23 \%$ & $45 \%$ & $18 \%$ & $8-15 \%$ \\
\hline
\end{tabular}

${ }^{1}$ U.S. Virgin Islands (Seaman 1952).

2 Pimentel (1955).

${ }^{3}$ Gorman (1975).

${ }^{4}$ Adriatic Sea (Cavallini and Serafini 1995). Many of the other data in this table were also recalculated by those authors.

${ }^{5}$ Baldwin et al. (1952).

${ }^{6}$ Mostello (1996). Unlike the other columns, these data reflect incidence, not percentage mass.

ECONOMIC IMPORTANCE AND ENVIRONMENTAL IMPACT

Impact on Bird Populations

Two bird species, both of them ground nesters, were probably driven to extinction by the small Indian mongoose. In Fiji, the barred-wing rail (Nesoclopeus poecilopterus) was described as common in 1875; in 1883, the mongoose was introduced, and within a few years the bird was extinct (Gorman 1975). Similarly, the Jamaica petrel (Pterodroma caribbaea) was abundant in the late eighteenth century; the mongoose was introduced to Jamaica in 1872, and this bird has not been seen since 1893 (Collar et al. 1992). A third possible case of mongoose-driven extinction, the Jamaican poorwill (Siphonorbis americanus), is more poorly evidenced. This bird has not been seen since 1859, and Bangs and Kennard (1920) proposed that the mongoose was responsible. However, later authors have doubted this, because the bird seems to have vanished over a decade before mongooses were introduced to Jamaica. Collar et al. (1992) blamed deforestation and rats.

Stone et al. (1994) stated, without citing sources, that the small Indian mongoose is a "known or suspected" nest predator upon at least eight federally listed endangered birds in Hawai'i. These include the nēnē or Hawaiian goose (Branta sandvicensis), the 'alalā or Hawaiian crow (Corvus bawaiiensis), the koloa or Hawaiian duck (Anas wyvilliana), the alae ke'oke'o or Hawaiian coot (Fulica alai), the ae'o or Hawaiian stilt (Himantopus mexicanus knudseni), the alae 'ula or Hawaiian gallinule (Gallinula chloropus sandvicensis), the "ua'u or Hawaiian petrel (Pterodroma sandwichensis), and the 'a'o or Newell shearwater (Puffinus auricularis newelli). Documentation of this predation is, however, rare. Land managers in Hawai'i frequently find signs of mammalian nest predation on protected birds but can rarely determine the species of predator. Baldwin et al. (1952) found remains of $\mathrm{Ha}-$ waiian petrels in 5 of 86 mongoose scats they examined from rocky pastures above $600 \mathrm{~m}$ elevation on leeward Hawai'i Island. King and Gould (1967) suggested, without citing sources, that the mongoose was responsible for the extirpation or reduction of the Newell shearwater on O'ahu, Moloka'i, Maui, and Hawai'i. Mongooses have also been blamed, again without citation of evidence, for local extirpations of the Hawaiian duck (Anonymous 1968).

Four once-common bird species have been extirpated from all Fijian islands with mongooses but persist on mongoose-free islands: the banded rail (Rallus philippensis), sooty rail (Porzana tabuensis), white-browed rail (Poliolimnas cinereus), and purple swamphen (Porpbyrio porpbyrio) (Gorman 1975). The uniform crake (Amaurolimnas concolor) was extirpated from Jamaica sometime after 1881, and Raffaele et al. (1998) opined that the mongoose may have been a major factor. 
On St. Croix, the bridled quail dove (Geotrygon mystacea) was originally a ground nester and was thought extinct in 1921, $47 \mathrm{yr}$ after the introduction of the mongoose. Nellis and Everard (1983) reported, however, that this bird had actually become an arboreal nester and had become fairly common. Allen (1911) blamed mongooses for the extirpation of a species of quail dove (genus Geotrygon) from St. Vincent. Wetmore (1927) blamed mongooses for the decline in Puerto Rico of five ground-nesting birds: two species of quail doves, the short-eared owl (Asio flammeus), the West Indian nighthawk (Chordeiles gundlachii), and the Puerto Rican nightjar (Caprimulgis noctitherus). The latter species was believed extinct for about $30 \mathrm{yr}$ before 1961 and now exists as an endangered species. It is found both in areas that do and do not contain mongooses, but is less abundant in the former (Vilella and Zwank 1987, 1993). The short-eared owl is also found sympatrically with the small Indian mongoose in Hawai' $i$, but the mongoose has not been cited as having a deleterious effect via predation on populations of the Hawaiian subspecies (Asio flammeus sandwichensis).

On St. Lucia and Martinique, the mongoose and other introduced predators presumably have added to the pressure that has reduced the populations of white-breasted thrasher (Ramphocinclus bracburus). But Collar et al. (1992) opined that these factors were less important than habitat destruction and competition by the bare-eyed thrush (Turdus nudigenis), an invasive species. After a long study of the effect of mongooses on Trinidad, Urich (1931) found that no birds had been extirpated, including ground-nesting species, during the $61 \mathrm{yr}$ since the mongoose's introduction.

The degree to which mongooses are responsible for the historical decline of bird species is often hard to assess, because of exacerbating factors such as introduction of rats, cats, dogs, and pigs, and habitat encroachment by human communities. It must be noted that any bird species now living in the presence of mongoose populations in Hawai'i has been doing so for over a century. It has been suggested that ground-nesting bird populations have established a predatorprey equilibrium with mongooses in the Caribbean (Westermann 1953). This may also be true in Hawaici, though it is surely also true that the mongoose's presence poses a substantial barrier to reestablishment of ground-nesting bird populations in their historical ranges.

\section{Impact on Mammal Populations}

Woods and Ottenwalder (1992) reported that bones found in owl pellets demonstrate that the following four species of small mammals were present on Hispaniola in 1930: the Haitian island shrew (Nesophontes hypomicrus), the small Haitian island shrew (N. zamicrus), the large Haitian island shrew (N. paramicrus), and the Hispaniolan spiny rat (Brotomys voratus). All four species are now believed extinct. The same authors proposed that the mongoose might have been a contributing factor to these extinctions, basing their opinion largely on the timing of the mongoose introduction, which they state variously as $\mathbf{1 8 9 5}$ (p. 109) or 1907 (p. 87).

Mongooses were introduced to Cuba in 1886 (Nellis and Everard 1983), and Westermann (1953) believed that mongooses were largely responsible for the extinction of the Cuban solenodon (Solenodon cubanus) (Insectivora: Solenodontidae) around 1910. This species has since been rediscovered in eastern Cuba, though it is still endangered (Nowak 1991).

There is a common story in Hawail $\mathrm{i}$ that small Indian mongooses failed to control rats in areas of introduction because the mongoose is diurnal and rats are primarily nocturnal (Stone et al. 1994). Most published accounts dispute this story, asserting that the small Indian mongoose served as an excellent cane-field ratter (Pemberton 1925, Barnum 1930, Doty 1945), though it was eventually made obsolete by the development of improved techniques of rat poisoning (Doty 1945).

On Trinidad, Urich (1931) found that rats were rare in cane fields, though they had been a major pest before the introduction of the mongoose in the 1870s. By 1882, a govern- 
ment botanist estimated that the mongoose in Jamaica was saving the colony 100,000 pounds sterling (current value: $\$ 8.3$ million) per year (Espeut 1882). Spencer (1950, cited by Seaman [1952]), however, found that roof rat populations were as high as 50 per hectare in some parts of St. Croix, despite the presence of mongooses. Seaman (1952) wrote that some cane fields on St. Croix still suffered $25 \%$ crop loss due to rats and believed that rats were as much a problem as before the introduction of the mongoose.

Another common story is that mongooses drove rats to become arboreal nesters in areas of introduction (Nellis and Everard 1983). On Hawaiian islands with mongooses, Polynesian rats (Rattus exulans) and Norway rats are terrestrial nesters, whereas roof rats are arboreal nesters. This appears to be true on islands with and without mongooses in $\mathrm{Ha}$ wai' $\mathrm{i}$ and throughout the world (Baldwin et al. 1952). There is, however, evidence that mongooses alter the relative abundance of rats in favor of arboreal roof rats (Walker 1945). In Puerto Rico, Norway rats are common only in mongoose-free urban areas, whereas roof rats are found in mongoose habitat (Pimentel 1955). Hoagland et al. (1989) made a census of populations of mongooses and rats on St. Croix and Jamaica, and found more roof rats and fewer Norway rats in mongoose habitat.

Nellis (1989) stated that mongooses "often dominate over" cats (Felis catus [domesticus]), though the degree to which they limit the abundance of feral cats in areas of sympatry has not been studied. Feral cats and wild mongooses peacefully share food at artificial feeding sites on $\mathrm{O}^{6} \mathrm{ahu}$, feeding within centimeters of each other (W.S.T.H., pers. obs.). More pertinently, on 3 June 1999, while doing a radio-tracking study, one of us (W.S.T.H.) observed two large male mongooses pass together within $3 \mathrm{~m}$ of an adult feral cat, in a relatively undisturbed woodlot and apparently by coincidence, without any of the animals involved showing any sign of excitement or stress even while making eye contact. This anecdotal observation suggests that adults of these species can coexist in peaceful sympatry, at least under some condi- tions, though it is also possible that they may harry or prey upon each other's young.

Seaman and Randall (1962) gave a description, including firsthand observations, of predation of mongooses upon fawns of the introduced white-tailed deer (Odocoileus virginianus) on St. Croix.

\section{Impact on Reptile and Amphibian Populations}

The reputation of the mongoose as an extinction-driver for Caribbean herpetofauna is partly due to exaggeration, though certainly mongooses do reduce populations of some reptiles and amphibians. Gosse (1851) reported that the Jamaica giant galliwasp (Celestus occiduus), an anguid lizard, was fairly abundant in the mid-1840s. It is now widely believed to be extinct, though at least one herpetologist has expressed doubts on this point (Crombie 1999). If this species is indeed extinct, the timing of its extinction is unclear, so it is hard to link this extinction firmly to the introduction of mongooses in 1872. Henderson and Sajdak (1996) stated that the mongoose was the primary cause of the apparent extinction of the Hispaniola racer (Alsophis melanichnus). Westermann (1953) reported that the mongoose had driven the black racer (Alsophis ater) extinct on Jamaica, but in fact this snake still exists, albeit in low numbers (Henderson 1992). Westermann (1953) and Nellis (1979) also blamed mongooses for the extinction of the Saint Croix racer (A. sanctaecrucis) on St. Croix in 1859 and the extirpation of the orange-bellied racer (A. rufiventris) on Nevis Island in 1879, but mongooses were not introduced to those islands until 25 and $21 \mathrm{yr}$, respectively, after the last official sightings of those snakes (Henderson 1992). Westermann (1953) further blamed mongooses for the extinction of several species of Dromicus snakes in the Lesser Antilles, though in fact these species were "never even close to being threatened" (Henderson 1992:6). Urich (1931) believed mongooses might have driven the skinks Mabuya aurata and $M$. agilis extinct on Trinidad, but these species persist today. He also blamed the mongoose for the possible extinction of the black tegu lizard 
(Tupinambis nigropunctatus) on Trinidad, but this species is now common again, despite the continuing presence of mongooses (Nellis and Everard 1983).

Mongooses apparently did, however, extirpate the Antiguan racer (Alsophis antiguae) from Antigua, the Martinique clelia snake (Liophis cursor) from Martinique, and the Santa Lucia groundsnake (L. ornatus) from St. Lucia. Each of these species persists on mongoose-free satellite islands (Henderson 1992). Corke (1987) blamed the mongoose for the extirpation of the windward clelia (Clelia clelia) and the skink Mabuya mabuya on St. Lucia, but Henderson (1992) believed the latter species too small and reclusive to be judged extirpated on existing evidence. The small Indian mongoose was introduced to Martinique and St. Lucia (dates of introduction unknown) to control the fer-de-lance (Bothrops atrox), a venomous species of pit viper (de Vos et al. 1956). Some authors blame (or credit) the mongoose with the extirpation of this snake on those islands (Barbour 1930, Nellis 1989), but it is uncertain whether mongooses actually attack these snakes in the wild. Hinton and Dunn (1967) stated that mongooses are commonly killed by the fer-delance in "fighting pit" shows, but Nellis and Everard (1983) believed that the mongoose usually wins.

In 1910, the small Indian mongoose was introduced to three Croatian islands to control the horned viper (Vipera ammodytes). In the same year, it was also introduced to Okinawa to control the habu pit viper (Trimeresurus flavoviridis). The effects of these two introductions on the local snake populations have not been studied.

The mongoose was largely responsible for the extirpation of the Saint Croix ground lizard (Ameiva polops) on St. Croix (Baskin and Williams 1966). These lizards had coexisted with mongooses for $90 \mathrm{yr}$, and were extirpated only when the sidewalks that were their final refuge were torn up in the late 1960s. Allen (1911) blamed the mongoose for the decline of Ameiva species in Grenada, but there have been no extirpations there (Henderson 1992).

Mongooses were probably largely respon- sible for the extirpation of the two largest skinks, Emoia nigra and E. trossula, from the two largest Fijian islands, Viti Levu and Vanua Levu (Zug 1991). These species vanished from those islands within a few years of the mongoose's arrival, and they are still found on mongoose-free Fijian islands. Case and Bolger (1991) made a census of diurnal lizard abundance on seven Pacific islands with mongooses and 11 islands without mongooses by walking transects in a variety of different habitat types. They found that there was nearly 100 times the abundance of diurnal lizards on mongoose-free islands.

Small Indian mongooses prey upon at least four endangered species of sea turtles. Nellis and Small (1983) documented 14 instances within a $2-y r$ period in which mongooses preyed upon the eggs or young of the hawksbill sea turtle (Eretmochelys imbricata) on Caribbean islands. A 1982 government study on St. Croix found that mongooses killed $5 \%$ of leatherback turtle (Dermochelys coriacea) hatchlings (unpubl. study, quoted by Nellis and Small [1983]). Seaman and Randall (1962) reported strong evidence of mongoose nest predation upon green sea turtles (Chelonia mydas). Nellis and Small (1983) stated that small Indian mongooses prey on nests of loggerhead sea turtles (Caretta caretta).

The edible frog Leptodactylus pentadactylus has been extirpated from the three Caribbean islands of its original range to which mongooses have been introduced but persists on two mongoose-free islands (Barbour 1930). Gorman (1975) found frog remains in mongoose scats collected from Fijian rain forests, suggesting that mongooses may have been the cause of the observed decline of two native ground frogs (Platymantis vitianus and P. vitiensis).

It is often hard to assess the degree of blame that should be affixed to mongooses in herpetofaunal decline. Nellis (1979) documented effects on the ecological community of a 5.5-ha Caribbean island when five pairs of mongooses were added experimentally. Within a year, a ground lizard (Ameiva exsul) had been extirpated, and, apparently as a result, prickly pear moths (Cactoblastis cactorum) and geckos of the genera Spaerodactylus and 
Hemidactylus had become more common. The flush in the moth population was accompanied by a crash of the prickly pear cactus (Opuntia) population. This experiment demonstrates that mongoose introductions can disrupt fragile island ecosystems and are capable of causing a herpetofaunal extirpation under some circumstances.

Henderson (1992) proposed that the mongoose was to blame for a few herpetofaunal extirpations in the Lesser Antilles but believed that habitat destruction was more to blame on the larger Caribbean islands. An even more conservative opinion was given by Corke (1992:47), who, after examining seven islands of the Lesser Antilles, stated, "There is no conclusive evidence for the widely reported role of introduced mongooses in the decline of the islands' reptiles."

\section{GEOGRAPHIC DISTRIBUTION IN THE PACIFIC REGION}

The small Indian mongoose is currently found on eight major Pacific islands. In Hawai' $i$ it is found on Hawai' $i$, Maui, Moloka' $i$, and O'ahu; in Fiji it is found on Viti Levu and Vanua Levu; and in Japan it is found on Okinawa and Amami.

\section{НАВITAT}

The small Indian mongoose is often reported to have an aversion to rain and water, which might suggest that xeric habitats should be preferred. This possibility is also supported by the observation that trap success in removal studies falls to near zero in rainy weather, even at usually successful sites (Nellis and Everard 1983) and even if the rain continues for several days (Nellis 1973).

No study has determined habitat preferences of small Indian mongooses in their native range. Lekagul and McNeely (1977:600) stated that in Thailand these animals "seem to prefer grasslands and secondary growth to dense forests." According to Corbet and Hill (1992), in the very dry northwestern portion of its native range the species is confined to mesic habitats and frequently is found around human habitation.
On the Caribbean islands of St. Croix and Trinidad, a comparison of population estimates from various habitats has shown that dry natural areas are preferred and rainy areas are avoided (Nellis and Everard 1983). Another Caribbean study, on St. John, also found that small Indian mongooses were more abundant in dry, low-elevation communities (Coblentz and Coblentz 1985).

In Hawai'i, however, wet areas are exploited by dense populations of mongooses. Baldwin et al. (1952) suggested that humid areas are even preferred by this species in $\mathrm{Ha}$ wai' $i$ and reported seeing an adult mongoose in deep forest in Kīpahulu Valley on Maui (annual rainfall: $750 \mathrm{~cm}$ per year); however, they added that this was a rare sighting. Tomich (1979) found a high density of mongooses in Waipi'o Valley, Hawai'i Island, where rainfall is 200 to $450 \mathrm{~cm}$ per year, depending on exact location.

The small Indian mongoose has been reported in Nepal (part of its natural range) at 2,200 m (Prater 1936). Baldwin et al. (1952) stated that it is found to elevations over 3,000 m in Hawai'i, but Tomich (1986) expressed doubts that Hawaiian populations exist much above 2,400 m elevation.

\section{HISTORY OF SMALL INDIAN MONGOOSE} INTRODUCTIONS

The small Indian mongoose has been introduced intentionally into wild habitats more widely than any other mammal (Figure 2). Indeed, all documented introductions of this species have been intentional, because of its reputation as a control agent upon rats and snakes. It is also an efficient predator upon many endangered and threatened vertebrates, and has been considered by at least one land manager to be "a vicious pest and wildlife's 'enemy No. 1'" (Seaman 1952:188).

The introduced small Indian mongoose is the only species of mongoose in the Western Hemisphere and Polynesia. In 1872, a sugar planter introduced four male and five female small Indian mongooses to Jamaica from eastern India (Espeut 1882). From Jamaica, mongooses eventually were introduced to 29 islands throughout the Caribbean and also to 
the northern coast of South America (Hoagland et al. 1989). An earlier New World introduction of some unknown mongoose species was made at Trinidad in 1870 (Urich [1914], cited in Hoagland et al. [1989]), but this and all other original Caribbean mongoose introductions apparently failed, except the one in Jamaica (Espeut 1882, Nellis and Everard 1983). Attempts were also made, before the introduction of mongooses, to introduce ferrets (Mustela putorius) to Jamaica, but these attempts also failed, purportedly due to chigoes ("burrowing fleas" [Tunga penetrans]) (Hinton and Dunn 1967).

The range of the small Indian mongoose on the South American mainland is limited to the developed coastal strip of Guyana, Surinam, and French Guiana (Nellis and Everard 1983), where it was introduced in 1900 (Hinton and Dunn 1967). The range of this mainland population appears to be limited, for now, by a boundary of swamp and rain forest (Nellis and Everard 1983). About 100 mongooses were also sent from Croatia to Venezuela in 1926 (Tvrtkovic and Krystufek 1990) but apparently did not establish there.

In 1883, sugar planters imported the small Indian mongoose from Jamaica to four Hawaiian islands (Hawai'i, O'ahu, Maui, and Kaua'i) and to the Fiiian island of Viti Levu (Gorman 1975, Nellis and Everard 1983). For unknown reasons, the crate of mongooses was kicked off the dock at Kaua $i$, and to date the mongoose has apparently not established there, although a dead mongoose was found in Kaua'i in 1976 (Tomich 1986). Mongooses were later introduced to the Hawaiian island of Moloka'i and to the Fijian island of Vanua Levu.

The small Indian mongoose exists on Java and Macau, and may have been introduced to these islands hundreds of years ago. More recently, it has been introduced to other islands of Indonesia and the Indian Ocean, including Ambon, Mauritius, and Mafia (Nellis and Everard 1983).

This species has been introduced to three Croatian islands of the Adriatic: Mljet (in 1910), Korcula (in 1910), and Hvar (in 1970 [Tvrtkovic and Krystufek 1990]). It was introduced to the Peljesac Peninsula in Croatia repeatedly in the 1920 s, and a population existed there as late as 1936 but apparently died out (Tvrtkovic and Krystufek 1990).

The small Indian mongoose was also successfully introduced to Okinawa in 1910 (Ogura et al. 1998) and to nearby Amami Island in 1949 and/or 1979 (Abe et al. 1991).

A failed attempt was made in the late nineteenth century to introduce a mongoose into Australia to control rabbits, but it is unknown whether this was the small Indian mongoose or another species (Hinton and Dunn 1967).

\section{PHYSIOLOGY AND BEHAVIOR}

Mean body temperature of small Indian mongooses is $39.5^{\circ} \mathrm{C}$. The mean resting heart rate is 252 beats per minute, and the mean resting respiratory rate is 63 breaths per minute (Nellis and Everard 1983). Metabolic energy use for this species, as deduced from oxygen consumption of restrained individuals, has been variously measured at $116 \mathrm{kcal} /$ $\mathrm{kg} /$ day (Lin and Kobayashi 1976) and 76 $\mathrm{kcal} / \mathrm{kg} / \mathrm{day}$ (Ebisu and Whittow 1976). The expected energy use for mammals in the size range of small Indian mongooses (300 to 600 $\mathrm{g}$ ) is 72 to $95 \mathrm{kcal} / \mathrm{kg} /$ day (Kleiber 1961). The thermal neutral zone is narrow and very high: 28 to $38^{\circ} \mathrm{C}$ (Ebisu and Whittow 1976). Small Indian mongooses are, however, able to maintain their body core temperature in the range of 0 to $41^{\circ} \mathrm{C}$, though they show signs of extreme heat stress at $45^{\circ} \mathrm{C}$ (Nellis and McManus 1974). Heat-stressed mongooses pant and salivate on their chest and forelimbs but do not lick them (Ebisu and Whittow 1976). They can respond to cold by raising their metabolic rate up to threefold (Nellis and McManus 1974).

The eye is emmetropic with at least $11 \mathrm{di}$ opters of accommodation (Nellis et al. 1989), and $25-40 \%$ of the photoreceptors are cones (Hope et al. 1982), suggesting that this species has unusually good vision for a small mammal and can discern colors. The kidney can achieve a urine concentration of $>6,000$ milliosmoles, suggesting adaptation to desert conditions (Nellis 1989). There is a large, appendix-like cecum (Palmiter and Horst 1982), but this appears to be lymphatic rather 
than digestive in character. Most fat is stored in the tail, which holds up to seven times the fat per mass of the body (Nellis and Everard 1983).

This species is entirely diurnal (Kavanau 1975). Typical movements are a low slink and a gallop. Small Indian mongooses can swim and climb trees (Nellis and Everard 1983) but rarely do so. When killing vertebrate prey, small Indian mongooses deliver a bite to the back of the head, crushing the skull. Foraging behavior has not been observed extensively or described in this species, because it tends to forage under cover and is difficult to observe for long, continuous periods. They form shallow burrows for use as dens.

Both male and female small Indian mongooses have a pair of pocket-shaped glands lateral to an extensible pouch around the anus, rich in sebaceous and apocrine glands (Gorman et al. 1974). These structures accumulate lipids and proteins that support grampositive bacteria, which produce a mixture of six saturated carboxylic acids. Mongooses use a "handstand" marking behavior to place this substance on vertical surfaces, supporting themselves on their forepaws while marking with the anal gland. Small Indian mongooses are able to distinguish between the scent marks of individual conspecifics in choice tests (Gorman 1976a), though the smell of these marks is undetectable by humans.

This species makes 12 distinct varieties of vocalization (Mulligan and Nellis 1973), including, for example, a contact call used by young mongooses when following their mother, a feeding call, and several agonistic cries that are graded by intensity of stress. Young small Indian mongooses show strong following responses, and follow their mother very closely until they are fully grown. Males show some degree of sociality during the breeding season (Hays and Conant 2003), but the social system has not been fully elucidated.

\section{REPRODUCTION AND POPULATION DYNAMICS}

Pregnant females are found from February through August in Hawai'i (Pearson and
Baldwin 1953), Fiji (Gorman 1976b), and the U.S. Virgin Islands (Nellis and Everard 1983), all of which are between 17 and 20 degrees of latitude either north or south of the equator. Grenada, which is at $12^{\circ} \mathrm{N}$, has a 10 -month breeding season (Nellis and Everard 1983). Males produce sperm year-round in Hawai $i$ (Pearson and Baldwin 1953), but the size of the testes changes seasonally: they are largest from February through July and smallest in October and November (Pearson and Baldwin 1953, Soares and Hoffman 1981). The size of the prostate gland follows the same cycle, as do serum levels of sex hormones (androgens, follicle-stimulating hormone, and luteinizing hormone) in males (Soares and Hoffman 1981). Sperm are also produced year-round in Fiji, where testes are largest from September to December (equivalent to March through June in the Northern Hemisphere) (Gorman 1976b).

Females have a 4-day estrus at 20-day intervals during the breeding season (Asdell 1964) plus postpartum estrus (Nellis and Everard 1983). Ovulation is induced by copulation (Asdell 1964). There is no delayed implantation (Tomich and Devick 1970), as there is in several other small carnivores (Sadleir 1969). Gestation takes 49 days, and pregnancy is not usually evident without dissection (Nellis and Everard 1983). Mean litter size is unknown, but examination of 255 wild-caught pregnant females on Grenada showed them to have a mean of 2.2 embryos, with a range of 1 to 5 (Nellis and Everard 1983). The number of litters produced annually by a typical female in the wild has not yet been determined with any certainty.

Pups begin accompanying their mother on hunting trips at 6 weeks of age (about $200 \mathrm{~g}$ body mass). Young mongooses follow their mothers until 4 to 6 months of age, at least in captivity, and this is also the range of ages at which both genders attain sexual maturity (Nellis and Everard 1983). The youngest wild-caught pregnant female with a confidently estimated age (determined by mass of the eye lens) was 4 months old (Nellis and Everard 1983).

Population densities have not been determined with certainty but may be extremely 
high in some regions of introduction, judging by the small size of individual home ranges found in a few studies. Nellis and Everard (1983) reported mean home ranges of 2.2 ha for two radio-tracked females and 3.6 ha for five radio-tracked males on St. Croix. Hays and Conant (2003) found mean home ranges of 1.4 ha for seven radio-tracked females on O'ahu. They also found that five radiotracked males had broadly overlapping home ranges in the breeding season, sharing a region of about 20 ha. All of these individual home ranges are very small, in comparison with those of typical small carnivores. Carnivores in the mass range of the small Indian mongoose (300 to $900 \mathrm{~g}$ ) are expected to have individual home ranges of 26 to 115 ha (Harestad and Bunnell 1979). No study has been done of the home ranges of small Indian mongooses in their natural range, but it may be speculated that populations are abnormally dense in many parts of the introduced range.

\section{MANAGEMENT}

Despite its wide range of introduction and its formidable reputation as a predator, the small Indian mongoose can only be confidently said to have driven three vertebrates to extinction anywhere in the world: the barred-wing rail, the Jamaica petrel, and the Hispaniola racer (and in each of those cases, there is room for doubt). Considering the great number of islands the mongoose has been introduced to, and the great number of ecologically delicate species it preys upon on these islands, this fact may at first seem remarkable. Many other common anthropically introduced mammals, such as cats, dogs, and rats, have probably caused more than two extinctions apiece. But this fact in itself may be a large part of the explanation of the relatively low number of extinctions directly attributable to mongoose introductions: the mongoose was a latecomer to its areas of introduction, and on most islands simply added one further burden to already-damaged ecosystems. By the time it arrived, much of the destruction was already done.

Nonetheless, the continued existence of the introduced mongoose is undoubtedly a major impediment to the reestablishment of many extirpated or reduced vertebrate populations on dozens of islands. In most of these locations, this is a role that the small Indian mongoose shares with other introduced predators, as well as introduced competitors and habitat degradation caused by human activities.

Almost all efforts at mongoose population management in areas of introduction have focused on the use of traps to remove individuals from ecologically sensitive areas. These areas include particularly the nesting sites of rare, ground-nesting birds. Trapping programs are of limited use, because removing the mongooses from a strip of habitat around the sensitive area creates a region of empty habitat that lures more mongooses into the area. These programs are also very expensive, because monitoring traps is a labor-intensive procedure.

Diphacinone, an anticoagulant that kills by internal hemorrhaging, first became available for experimental use in 1988. It has proved to be especially effective against mongooses, but its use as a control agent is still primarily experimental (Keith et al. 1990, Smith 1998), and it is not currently being widely dispersed in areas inhabited by introduced mongooses.

\section{PROGNOSIS}

The small Indian mongoose is strongly entrenched in most of its areas of introduction. It appears to have high population densities on many large islands, is often found in habitat that would have been unsuitable for it within its natural range, and in some places (e.g., Hawai'i) has no natural predators and few communicable diseases and parasites. Only the most drastic measures, such as aerial dispersion of diphacinone bait pellets, would have any chance of eliminating such populations from even small islands, and the ecological costs of such efforts might outweigh their benefits in many cases. Perhaps the single most crucial management issue is to prevent the further spread of the species. Fortunately, new small Indian mongoose populations are not likely to become established without 
human agency, though this could occur unintentionally (e.g., by release of pet mongooses).

\section{ACKNOWLEDGMENTS}

We thank an anonymous reviewer who supplied us with several useful references.

\section{Literature Cited}

Abe, S., Y. Takatsuki, Y. Handa, and H. Nigi. 1991. Establishment in the wild of the mongoose (Herpestes sp.) on Amamioshima Island. Honyurui Kagaku 31:2336.

Allen, G. M. 1911. Mammals of the West Indies. Harv. Coll. Mus. Comp. Zool. Bull. $54: 175-263$.

Anonymous. 1968. The mongoose. Circular. Hawai'i Division of Fish and Game, Honolulu.

Asdell, S. A. 1964. Patterns of mammalian reproduction. 2nd ed. Cornell University Press, Ithaca, New York.

Baldwin, P. H., C. W. Schwartz, and E. R. Schwartz. 1952. Life history and economic status of the mongoose in Hawaii. J. Mammal. 33:335-356.

Bangs, O., and F. H. Kennard. 1920. A list of the birds of Jamaica. Government Printing Office, Kingston, Jamaica.

Barbour, T. 1930. Some faunistic changes in the Lesser Antilles. Proc. N. Engl. Zool. Club 9:73-85.

Barnum, C. C. 1930. Rat control in Hawaii. Hawaii. Plant. Rec. 34:421-443.

Baskin, J. N., and E. E. Williams. 1966. The Lesser Antillean Ameiva (Sauria, Teiidae). Stud. Fauna Curacao Other Caribb. Isl. 89:144-176.

Case, T., and D. T. Bolger. 1991. The role of introduced species in shaping the distribution and abundance of island reptiles. Evol. Ecol. 5:272-290.

Cavallini, P., and P. Serafini. 1995. Winter diet of the small Indian mongoose, Herpestes auropunctatus, on an Adriatic island. J. Mammal. 76:569-574.

Coblentz, B. E., and B. A. Coblentz. 1985. Reproduction and the annual fat cycle of the mongoose on St. John, US Virgin Islands. J. Mammal. 66:560-563.

Collar, N. J., L. P. Gonzaga, N. Krabbe, A. Madrono Nieto, L. G. Naranjo, T. A. Parker III, and D. C. Wege. 1992. Threatened birds of the Americas. Smithsonian Institution Press, Washington, D.C.

Corbet, G. B., and J. E. Hill. 1992. The mammals of the Indomalayan region. Oxford University Press, Oxford, United Kingdom.

Corke, D. 1987. Reptile conservation on the Maria Islands (St. Lucia, West Indies). Biol. Conserv. 40:263-279.

- 1992. The status and conservation needs of the terrestrial herpetofauna of the Windward Islands (West Indies). Biol. Conserv. 62:47-58.

Crombie, R. I. 1999. Jamaica. Pages 63-92 in B. I. Crother, ed. Caribbean amphibians and reptiles. Academic Press, San Diego.

de Vos, A., R. H. Manville, and R. G. van Gelder. 1956. Introduced animals and their influence on native biota. Zoologica 41:163-194.

Doty, R. E. 1945. Rat control on Hawaiian sugar cane plantations. Hawaii. Plant. Rec. 49:71-239.

Ebisu, R. J., and G. C. Whittow. 1976. Temperature regulation in the small Indian mongoose (Herpestes auropunctatus). Comp. Biochem. Physiol. A Comp. Physiol. 54:309-313.

Espeut, W. B. 1882. On the acclimatization of the Indian mongoose in Jamaica. Proc. Zool. Soc. Lond. 1882:712-714.

Fredga, K. 1965. New sex determining mechanism in a mammal. Nature (Lond.) 206:1176.

Gorman, M. L. 1975. The diet of feral Herpestes auropunctatus (Carnivora: Viverridae) in the Fijian Islands. J. Zool. 175:273-278.

- 1976a. A mechanism for individual recognition by odour in Herpestes auropunctatus. Anim. Behav. 24:141-145.

- 1976b. Seasonal changes in the reproductive pattern of feral Herpestes auropunctatus in the Fijian Islands. J. Zool. 178:237-246.

Gorman, M. L., D. B. Nedwell, and R. M. Smith. 1974. An analysis of the anal scent 
pockets of Herpestes auropunctatus. J. Zool. 172:389-399.

Gosse, P. H. 1851. A naturalist's sojourn in Jamaica. Longman, London.

Harestad, A. S., and F. L. Bunnell. 1979. Home range and body weight-a reevaluation. Ecology 60:389-402.

Hays, W. S. T., and S. Conant. 2003. Male social activity in the small Indian mongoose, Herpestes javanicus. Acta Theriol. 48:485-494.

Henderson, R. W. 1992. Consequences of predator introductions and habitat destruction on amphibians and reptiles in the Post-Columbus West Indies. Caribb. J. Sci. 28:1-10.

Henderson, R. W., and R. A. Sajdak. 1996. Diets of West Indian racers (Colubridae: Alsophis): Composition and biogeographic implications. Contrib. Herpetol. 12:327338.

Hinton, H. E., and A. M. S. Dunn. 1967. Mongooses: Their natural history and behavior. Oliver and Boyd, Ltd., London.

Hoagland, D. B., G. R. Horst, and C. W. Kilpatrick. 1989. Biogeography and population biology of the mongoose in the West Indies. Pages 611-634 in C. A. Woods, ed. Biogeography of the West Indies. Sandhill Crane Press, Gainesville, Florida.

Hope, G. M., W. W. Dawson, R. Parmer, M. N. Hawthorne, and D. W. Nellis. 1982. The mongoose: A potentially useful animal for retina research. Invest. Ophthalmol. Visual Sci. 22 (suppl.): 56.

Kavanau, J. L. 1975. Influences of light on activity and phasing of carnivores. Am. Nat. 109:391-417.

Keith, J. O., D. N. Hirata, D. L. Espy, S. Greiner, and D. Griffin. 1990. Field evaluation of $0.00025 \%$ diphacinone bait for mongoose control in Hawaii. Unpublished report, Denver Wildlife Research Center, Denver, Colorado. Available from the Denver Wildlife Research Center.

King, W. B., and P. J. Gould. 1967. The status of Newell's race of the Manx shearwater. Living Bird 6:163-186.

Kleiber, M. 1961. The fire of life: An introduction to animal energetics. John Wiley and Sons, New York.
La Rivers, I. 1948. Some Hawaiian ecological notes. Wasmann Collect. 7:85-110.

Lekagul, B., and J. A. McNeely. 1977. Mammals of Thailand. Sahaharnbhat, Bangkok.

Lin, Y. C., and R. H. Kobayashi. 1976. Cardiovascular functions of the unanesthetized mongoose Herpestes auropunctatus. Comp. Biochem. Physiol. A Comp. Physiol. 53:375-379.

Mostello, C. S. 1996. Diets of the pueo, the barn owl, the cat and the mongoose in Hawai'i: Evidence for competition. M.S. thesis, University of Hawai'i at Mānoa, Honolulu.

Mulligan, B. E., and D. W. Nellis. 1973. Vocal repertoire of the mongoose Herpestes auropunctatus. Behaviour 55:237-267.

Nellis, D. W. 1973. The biology of the mongoose (Herpestes auropunctatus) on St. Croix. Ph.D. diss., University of Georgia, Athens.

1979. Mongoose influence on the ecology of islands. Trans. Int. Congr. Game Biol. 14:311-314.

- 1989. Herpestes auropunctatus. Mamm. Species 342:1-6.

Nellis, D. W., and C. O. R. Everard. 1983. The biology of the mongoose in the Caribbean. Stud. Fauna Curacao Other Caribb. Isl. 195:1-162.

Nellis, D. W., and J. J. McManus. 1974. Thermal tolerance of the mongoose, Herpestes auropunctatus. J. Mammal. 55:645-646.

Nellis, D. W., J. G. Sivac, W. N. MacFarland, and H. C. Howland. 1989. Characteristics of the eye of the Indian mongoose (Herpestes auropunctatus). Can. J. Zool. 67:2814-2820.

Nellis, D. W., and V. Small. 1983. Mongoose predation on sea turtle eggs and nests. Biotropica 15:159-160.

Nowak, R. M. 1991. Walker's mammals of the world. 5th ed. Johns Hopkins University Press, Baltimore.

Ogura, G., M. Sakashita, and Y. Kawashima. 1998. External morphology and classification of mongoose on Okinawa Island. Honyurui Kagaku 38:259-270.

Palmiter, P. L., and G. R. Horst. 1982. Morphology of the gastrointestinal tract of the mongoose Herpestes auropunctatus. Anat. Rec. 202:144A. 
Pearson, O. P., and P. H. Baldwin. 1953. Reproduction and age structure of a mongoose population in Hawaii. J. Mammal. 34:436-447.

Pemberton, C. E. 1925. The field rat in Hawaii and its control. Bull. Exp. Stn. Hawaii. Sugar Planters' Assoc., Entomol. Ser. 17.

Pimentel, D. 1955. Biology of the Indian mongoose in Puerto Rico. J. Mammal. 36:62-68.

Prater, S. H. 1936. The wild animals of the Indian Empire and the problem of their preservation, part IV. J. Bombay Nat. Hist. Soc. 38 (suppl.): 189-219.

Raffaele, H., J. Wiley, O. Garrido, A. Keith, and J. Raffaele. 1998. A guide to the birds of the West Indies. Princeton University Press, Princeton, New Jersey.

Sadleir, R. M. F. S. 1969. The ecology of reproduction in wild and domesticated animals. Methuen and Co., London.

Seaman, G. A. 1952. The mongoose and Caribbean wildlife. Trans. N. Am. Wildl. Conf. 17:188-197.

Seaman, G. A., and J. E. Randall. 1962. The mongoose as a predator in the Virgin Islands. J. Mammal. 43:544-546.

Smith, D. 1998. Efficacy of J. T. Eaton bait blocks rodenticide with fish flavorizer for controlling Indian mongoose (Herpestes auropunctatus) populations in wild land areas. Report to Hawai'i Department of Forestry and Wildlife, Division of Land and Natural Resources, Honolulu. Available from the Department of Forestry and Wildlife, Honolulu.

Soares, M. J., and J. C. Hoffman. 1981. Seasonal reproduction in the mongoose, Herpestes auropunctatus. I: Androgen, luteinizing hormone, and follicle stimulating hormone in the male. Gen. Comp. Endocrinol. 44:350-358.

Stone, C. P., M. Dusek, and M. Aeder. 1994. Use of an anticoagulant to control mongooses in nene breeding habitat. 'Elepaio $54: 73-78$

Tomich, P. Q. 1979. Studies of leptospirosis in natural host populations. I. Small mam- mals of Waipio Valley, island of Hawaii. Pac. Sci. 33:257-279.

. 1986. Mammals in Hawaii. 2nd ed. Bishop Museum Press, Honolulu.

Tomich, P. Q., and W. S. Devick. 1970. Age criteria for the prenatal and immature mongoose in Hawaii. Anat. Rec. 167:107114.

Tvrtkovic, N., and B. Krystufek. 1990. Small Indian mongoose, Herpestes auropunctatus (Hodgson 1836) on the Adriatic islands of Yugoslavia. Bonn. Zool. Beitr. 41:3-8.

Urich, F. W. 1914. The mongoose in Trinidad and methods of destroying it. Board of Agriculture Trinidad and Tobago Circular 12:5-12.

. 1931. The mongoose in Trinidad. Trop. Agric. 8:95-97.

Vilella, F. J., and P. J. Zwank. 1987. Density and distribution of the Puerto Rican nightjar in the Guayanilla Hills. Caribb. J. Sci. 23:238-242.

. 1993. Ecology of the small Indian mongoose in a coastal dry forest of Puerto Rico where sympatric with the Puerto Rican nightjar. Caribb. J. Sci. 29:24-29.

Walker, L. W. 1945. The Hawaiian mongoose-friend or foe. Nat. Hist. 54:396400.

Westermann, J. H. 1953. Nature preservation in the Caribbean. Publ. Found. Sci. Res. Surinam Neth. Antilles 9:1-106.

Wetmore, A. 1927. The birds of Porto Rico and Virgin Islands. New York Academy of Sciences, Scientific Survey of Porto Rico and the Virgin Islands 9 (3 \& 4): 254-571.

Wolcott, G. N. 1953. The food of the mongoose (Herpestes javanicus auropunctatus Hodgson) in St. Croix and Puerto Rico. J. Agric. Univ. P. R. 37:241-247.

Woods, C. A., and J. A. Ottenwalder. 1992. The natural history of southern Haiti. University of Florida Press, Gainesville.

Zug, G. R. 1991. The lizards of Fiji: Natural history and systematics. Bishop Museum Press, Honolulu. 